PROBLEMS

OF MANAGEMENT

IN THE $21^{\text {st }}$ CENTURY

Volume 4,2012

\title{
EFFECT OF FRAUD RISK REDUCTION STRATEGY ON THE LEVEL OF EMPLOYEE FRAUD IN NIGERIAN PUBLIC SERVICE ORGANIZATIONS
}

\author{
Joe Duke II, Kechi A. Kankpang \\ University of Calabar, Calabar, Nigeria \\ E-mail: joedukell@yahoo.com, kankpang_2000@yahoo.com
}

\begin{abstract}
Given the rampant headline revelations of widespread fraud perpetrated in Nigerian public service organizations in recent times, this study addresses a topical subject that commands urgent attention, understanding and intervention. Using a survey design and case approach, a cross-sectional study was carried out on a sample of 54 systematically selected public service organizations spread across the SouthSouth geopolitical region of Nigeria. The study showed that the fraud risk reduction strategy deployed in Nigerian public service organizations is not effective in reducing the overall level of employee fraud. The study showed that auditor's monitoring strength is low. It also found that the prevailing reward and compensation system does not facilitate reduction of incentive for employee fraud. These results point to a need to review, strengthen and make more dynamic and responsive the current fraud risk reduction strategy used.
\end{abstract}

Key words: employee fraud, organizations, Nigeria.

\section{Introduction}

In addition to the range of obvious costs usually incurred by organizations in operations, a number of latent, hidden or non-obvious costs, such as absenteeism, loafing, shirking, corruption, fraud and abuse are also important. Of these latent costs, fraud and abuse arguably present the greatest threat to the efficiency and attainment of the profit or other objective of organizations. The effects of fraud are often cumulative and circular (Asomugha, 1997). Frequent occurrences of fraud ultimately distract the attention of management and lead to increased running cost. Time, energy and other resources that would have been spent on improving service delivery are rather expended on preventing, detecting and controlling fraud. The cost of fraud is ultimately transferred to the consumer in the form of high prices, short-change and opportunity costs. The problem with fraud is that it mainly has to do with people's behaviour and is therefore relatively difficult to predict, budget or account for. The associated costs are not apparent until its dimensions are fully discovered or unraveled.

Fraud in the context of this paper includes deceitful acts or trickery perpetrated to the detriment of another person or entity, and aimed at gaining some advantage dishonestly (Oludife, 1994; Comer, 1995). While fraud cannot be considered to be a normal or expected human behaviour, its prevalence in organizations and society make it appear a somewhat natural phenomenon. The incidence of fraud, and its concomitant outcomes, finds form in the opportunistic behaviour of employees, managers and clients, loose management control systems and poor corporate governance infrastructures. Political, social, cultural and attitudinal factors combine in contributing to the rampancy of fraud. This problem is a global phenomenon 
that has brought down numerous firms across a wide variety of industries, sectors and countries. No organization is immune to fraud, as it permeates virtually all facets of society - government, trade, shipping transactions, sports, banking and insurance, air travel and even religious organizations (Nwankwo, 1991).

\section{Problem of Research}

The issue of employee fraud and abuse appears to assume a more serious dimension and importance in public service organizations in the developing world. In Nigeria for instance, fraud and abuse easily account for the bulk of losses of public and private funds (Shongotola, 1994). Recent statistics show that the phenomenon is growing exponentially in magnitude and impact. Within the last two years, reported cases of financial fraud involving public organizations included the theft of \$20million of the Nigeria Police Force pension fund by public servants, and execution of fuel subsidy scams amounting to $\$ 9.93$ million by civil servants in collusion with petroleum products vendors (Soniyi, 2012; Naijafeed, 2012; NairaLand, 2012). Similarly, a recent biometric audit of 36 Federal public service establishments consisting of ministries, departments and agencies (MDAs) revealed that 43,000 of the employees, amounting to 38\% of the total on the nominal roll, did not exist or were fake (SecurLinx.com, 2011). A similar trend persists in the banking sector, where losses owing to fraud by bank staffs rose from an average annual of \$5million in 1990 to \$20million by 1998 (Uche, 2001). More recently, the Central Bank of Nigeria reported that attempts at fraud in banks had risen sharply by $55 \%$ between 2010 and 2011, with a total of \$31.2million involved (Osae-Brown \& Uzor, 2011). While most other countries have been able to reduce the occurrence of financial fraud in both the private and public sectors, the menace is rather on the increase in Nigeria. The country has reportedly continued to slide freely down the corruption index - where it is currently scored 2.4 , on a scale of $0-10$, with 0 being a highly corrupt country and 10 a very clean one (TI, 2011).

Regulatory agencies and firms have over time responded in a number of ways, and with a variety of instruments towards curbing the menace of fraud. In spite of this, the problem continues to escalate unabated, pointing to serious shortcomings in the measures typically used, especially in large public service organizations.

\section{Research Focus and Objectives}

This study basically approaches the fraud risk problem from an organizational perspective, by attempting to provide an understanding of the effect of the fraud risk reduction strategy used in Nigerian public service organizations on the level of employee fraud. It also seeks to establish the effect of reduction of the level of fraud on employee productivity. The main purpose is to examine the extent to which the current strategy used has been effective both in reducing the fraud level and facilitating employee productivity.

\section{Theoretical Framework and Applicability to Research Hypotheses}

A number of theories have formed the framework for this study. The General Systems Theory, which suggests that an organization is best viewed from the perspective of an open system because of its constant interaction with the environment, provides a number of interesting propositions that explain the elements and prerequisites of an effective management control system. The implication of this is that the design of an organization's management control systems, of which internal controls is a major component, should necessarily commence with an 
PROBLEMS

OF MANAGEMENT

IN THE $21^{\text {st }}$ CENTURY

Volume 4, 2012

32

characterized by dynamic and volatile changes that may pose constant threats to the operations of the organization, or if it is benign, predictable and stable (Ansari, 2004). Similarly, the Agency theory takes the view that conflict of interest usually characterizes the contractual relationship between stockholders and managers, and the main problem organizations face in this regard is how to manage the conflict in a way that will help reduce opportunistic behaviour. Managing the agency problem is complex in the sense that organizational owners cede control of the firm to the board and managers under an agency contract. The organizational owners however consequently become hostages to their agents, whom the theory assumes will always place their own personal goals ahead of the organization's and its owners (Mintz, 2004). Although, shareholders normally expect that their agents will act in the principal's best interest, reality however suggests the contrary (Padilla, 2000). Because of this problem, the Agency theory essentially implies that the best way to reduce the agency problem is to institute a resilient, dynamic and responsive internal control system that can anticipate and respond to opportunistic behaviour of organizational managers and other members. A number of measures that facilitate internal control have been suggested, but the most relevant and instructive here are separation of the headship of the board of directors from the office of the CEO, and controlling managers through board action, including firing those whose actions do not meet the expectations of the board (Mintz, 2004; Duke, Kankpang \& Okonkwo, 2012). The General Systems and Agency theories address and directly speak to the first hypothesis of this study:

\section{H1: Internal controls system significantly reduces the level of risk of employee fraud in Nigerian public service organizations.}

The Theory of Concealment describes two fraud types, on-book or off-book (Nystrom, 1997). On-book fraud occurs during the normal course of an organization's business activities and is usually concealed in the organization's regular books or records; only careful examination or forensic skills can reveal it. Even though on-book frauds may seem totally hidden, an audit trail normally exists (Thornhill, 1995). Off-book fraud on the other hand occurs outside the accounting system and leaves no audit trail. For such fraud to be successfully perpetrated, the organization must have unrecorded vendor rebates or significant cash-based transaction with customers and vendors. Typical off-book frauds take the form of bribes, kickbacks and other illicit payments. Off-book frauds are usually detected from sudden change in lifestyle or consumption pattern of staff, without a corresponding increase in wage or other legitimate income. Once a significant anomaly is detected, a fraud investigation can be initiated in order to establish the extent and nature of the fraud. A related hypothesis is the Theory of Deviation, which posits that because fraud is a socially unacceptable behaviour, its perpetrators usually attempt to conceal guilt and hide their wrong-doing because they do not want to be discovered, and in their attempt to do this they often exhibit abnormal behaviour. Therefore, deviations from the accepted procedures at the workplace are often the first indication of this type of fraud (Thorhill, 1995). The Audit Quality Theory proposes a remedy that focuses on the use of audit as an instrument for addressing employee fraud. The central theme of this theory is that audit quality increases with auditor's monitoring strength. Audit quality is the probability that an auditor will both discover and truthfully report a discovered breach. The probability of reporting is a function of independence (DeAngelo, 1981a; Watts \& Zimmerman, 1981, 1986). Since high quality, independent auditors are more likely to detect and object to the client firms' use of aggressive and questionable accounting practices, earnings management is expected to decrease as audit quality improves. DeAngelo (1981b) suggests that an existing audit client provides the auditor with client-specific rents that the auditor expects to receive during the 
life of the auditor-client relationship. This source of perpetual rents may create an economic dependency of the auditor on the client. While the incumbency exists, auditors may be willing to

PROBLEMS OF MANAGEMENT IN THE $21^{\text {st }}$ CENTURY Volume 4, 2012 acquiesce to the wishes of client management, thus compromising their independence (Magee \& Tseng, 1990). Also, the possibility of being terminated by a client could affect auditor's reporting decisions (Raghunathan, Lewis \& Evan, 1994). If the length of the auditor-client relationship is limited, thereby lowering the expected period of incumbency and the expected rents, then the auditor would have greater incentive to resist management pressure (AICPA, 1992; Dopuch, King \& Schwartz, 2001; Gietzmen \& Sen, 2002). The theories of concealment and deviation and audit quality address the second hypothesis of this study:

H2: Auditors' monitoring strength significantly reduces the level of risk of employee fraud in Nigerian public service organizations.

The Employee Theft Theory holds that employees steal primarily as a result of work place conditions, and that the true financial estimates and costs of the problem are grossly under stated (Hollinger \& Clark, 1983; Wells, 1997). This theory has 5 inter-related sets of underpinnings: external pressure, arising from unsharable or private financial burden; contemporary employees, specifically young ones, are not as hardworking and honest as those in past generations; and, every employee can be tempted to steal from his employer; people are greedy and predisposed to dishonesty by nature; job dissatisfaction is the primary cause of employee theft; and, theft occurs because of the broadly shared formal and informal structure of organizations, which over time encourages group norms, be they good or bad, to become the standard of conduct for its members (Hollinger \& Clark, 1983; Cressey, 1993). Implicit in this theory is the proposition that substantially increasing the internal security presence does not seem effective or even appropriate, given the prevalence of the problem of fraud in organizations. Indeed, it may be counterproductive and worsen the incidence of fraud. Secondly, the same employees who engage in other deviant workplace behaviours, such as, slow and sloppy workmanship, sick-leave abuse, late-coming/early leaving, long coffee breaks, alcohol and drug use, are also principally the ones who engage in employee theft. The theory also indicates that if efforts are made to reduce employee theft without reducing its underlying causes, such as employee dissatisfaction and lack of ethics, the result could deceptively bring down fraud occurrences, while pushing up other cost-consuming behaviours perpetrated by employees. Fourthly, the theory argues that increased management sensitivity will reduce all forms of deviant workplace behaviours. Finally, the theory suggests that special attention be paid to the needs of younger employees, as they are the ones that are most likely to steal. Nevertheless, while the incidence of theft is higher among younger employees, the resultant losses are typically lower than those of more senior employees with financial authority (Wells, 1997). A concomitant to the Employee Theft Theory is the Psychological Contract Theory. Psychological contract is the idiosyncratic set of reciprocal expectations held by employees concerning their obligations and their entitlements to/from the organization (McLean Parks, Kidder \& Gallagher, 1998). This theory considers trust to be pervasive in the organization by assuming that employees are honest and ethical. They typically are engaged in a reciprocal relationship with the organization, and therefore expect that as they deliver on their own contractual obligations, so will the organization meet its own part of the bargain. Employee misconduct therefore only occurs when the psychological contract is violated and the employee perceives some injustice or unfair treatment in the workplace (Kidder, 2005). In other words, honest and ethical employees may commit acts of misconduct when they feel that they have been subjected to work in an unjust environment or that trust has been violated (Morrison \& Robinson 1997; McLean Park \& Kidder, 1994). Both the Employee Theft and Psychological Contract theories address the third hypothesis of the study:

H3: The reward and compensation system significantly reduces the level of risk of employee fraud in Nigerian public service organizations. 
One of the notable outcomes of unethical behaviours is increased occupational fraud and misconduct. And, according to the Association of Certified Fraud Examiners, fraud and other unethical behaviours, in turn, undermine and worsen employee productivity (cited in Josephson Institute, 2004). Understandably, a significant relationship exists between poor ethics at the workplace and low productivity. Key to creating an ethical organization is the development and institution of a clear and espoused code of ethics that all members subscribe to. A study by Webley and Moore (2003) indicates that organizations without a code of ethics generally do worse in their overall productivity level, as unethical behaviours and their effects tend to pervade the system. Under such circumstances, employees' propensity to commit fraud often heightens. In an ethics survey, it was established that the presence of an ethics program helps increase the reporting of misconduct by employees. There is a $78 \%$ reporting of unethical behaviour in organizations with a standard of ethics, but this level drops significantly to $39 \%$ in organizations that have none (ERC, 2003). The connection between employee fraud and productivity is tested in the fourth hypothesis of this study:

H4: Reduction in the level of fraud has a significant effect on the productivity of employees in Nigerian public service organizations.

\section{Methodology of Research}

This study basically seeks to examine the effect of the fraud risk reduction strategy used in Nigerian public service organizations on the level of employee fraud. It also attempts to establish a relationship between the level of employee fraud and productivity. In testing the effect of fraud risk reduction strategy on the level of employee fraud, the internal controls system, auditors' monitoring strength and reward and compensation system were used as the independent variables. Subsequently, the relationship between reduction in the level of fraud and employee productivity is tested, with reduction in employee fraud as the independent variable. The study area for the research was the South-South region, which is one of the geo-political zones of Nigeria, made up of 6 out of a total of 36 states. Specifically, this zone comprises Akwa Ibom, Bayelsa, Cross River, Delta, Edo and Rivers States. Given the similarity or homogeneity of the public service system in Nigeria, the results obtained from the chosen study area, SouthSouth region, sufficiently represent the experience across the rest of the country.

\section{Sample of the Research}

The study population consisted of the workforce of the public service establishments or MDAs in the six states of the South-South region of Nigeria. The aggregate population of the workforces was 137,581 persons. A systematic sampling technique that involved the selection of the first of every four MDAs listed in an alphabetical order was adopted by the researchers. This was replicated across the 6 states, thus resulting in the initial sampling of a total of 54 MDAs across the region. The combined staff population of the selected MDAs was 38,219, distributed as follows for each of the 6 six states: 7,197, 3,080, 6,119, 6,938, 6,848, 8,037 for Akwa Ibom, Bayelsa, Cross River, Delta, Edo and Rivers States respectively. The residual study population amounted to $27.78 \%$ of the total in the region. Ten percent of a cross-section of this residual population was randomly selected to form the eventual sample for the study, amounting to a total of 3,822 respondents. 
Joe DUKE II, Kechi A. KANKPANG. Effect of Fraud Risk Reduction Strategy on the Level of Employee Fraud in Nigerian Public Service Organizations

\section{Instrument and Procedure}

A structured questionnaire was developed as the main instrument for the survey. This questionnaire was a 4-part, 5-scale Likert scale instrument designed to elicit answers appropriate responses to the issues surrounding the research hypotheses. The sections focused on internal controls system, auditors' monitoring strength, employees' reward and compensation system, the level of risk of employee fraud, employee productivity and respondent biographic information. The research instrument was extensively peer-reviewed in order to ensure its content, construct and criterion validity. For the purpose of establishing reliability, a test-retest procedure was adopted. Under it, the questionnaire was administered on 20 respondents randomly selected from 10 MDAs that did not fall under the chosen study sample across 2 states at the rate of 10 test respondents per state. The test and retest were conducted at a 2-week interval. Using Results the product moment correlation coefficient (' $r$ ') statistical tool, the 2 sets of samples showed that ' $r$ ' $=0.73$. This indicated a high degree of relationship between the result of both the test and retest samples. This indicated sufficient reliability of the instrument. Based on this, the research responses were adjudged to be reliable. Seasoned field survey operatives were then deployed across the six states to administer and retrieve the research questionnaire. A $70.5 \%$ research instrument retrieval rate was achieved. A select number of case studies were also conducted in order to further assess the fraud management strategies used in the sample organizations.

\section{Data Analysis}

The ordinary least square (OLS) regression analysis and the coefficient of correlation statistical tools were used in establishing the relationship between the various variables in the study. Tables were used to present the results for each of the variables in the study.

Model specification

The models used in establishing these relationships are expressed as follows:

EMFRALEV $={ }_{\mathrm{x} 0}+\mathrm{x}_{1}$ INTCTRSYS $+\mathrm{x}_{2}$ AUMOST $+\mathrm{x}_{3}$ RECOMSY $+\mathrm{x}$

$+\mathrm{e}_{\mathrm{t}} \ldots . . .(1)$

EMPROD $={ }_{\mathrm{x} 0}+{ }_{\mathrm{x} 1}$ RDFRALEV $+{ }_{\mathrm{x}}+\mathrm{e}$

Where $\mathrm{x}_{1>0}, \mathrm{x}_{2>0}, \mathrm{x}_{3<>0}$

Table 1 shows a description of the variables used in the model.

Table 1. Variable description.

\begin{tabular}{|c|c|c|}
\hline Variable description & Definition & Type \\
\hline EMPROD & Employee productivity & Dependent \\
\hline EMFRALEV & Employee fraud level & Dependent \\
\hline INTCTRSYS & Internal controls system & Independent \\
\hline AUMOST & Auditor's monitoring strength & Independent \\
\hline RECOMSY & Reward and compensation system & Independent \\
\hline RDFRLEV & Reduction in fraud level & Independent \\
\hline
\end{tabular}


PROBLEMS

OF MANAGEMENT IN THE $21^{\text {st }}$ CENTURY Volume 4, 2012
In the first equation, employee fraud level (EMFRALEV) is the dependent variable while internal controls system (INTCTRSYS), auditors' monitoring strength (AUDMOST) and reward and compensation system (RECOMSYS) are the independent variables. In the second equation, employee productivity (EMPROD) is the dependent variable while reduction in the level of employee fraud (RDFRALEV) is the independent variable. The error term, $e_{t}$, represents some residual contributions to employee productivity and the level of fraud arising from errors in the measurement of internal controls, auditor's monitoring strength and reward and compensation system.

\section{Results of Research}

Table 1. Least square regression results for the effect of internal controls system used on the level of employee fraud in Nigerian public service organizations.

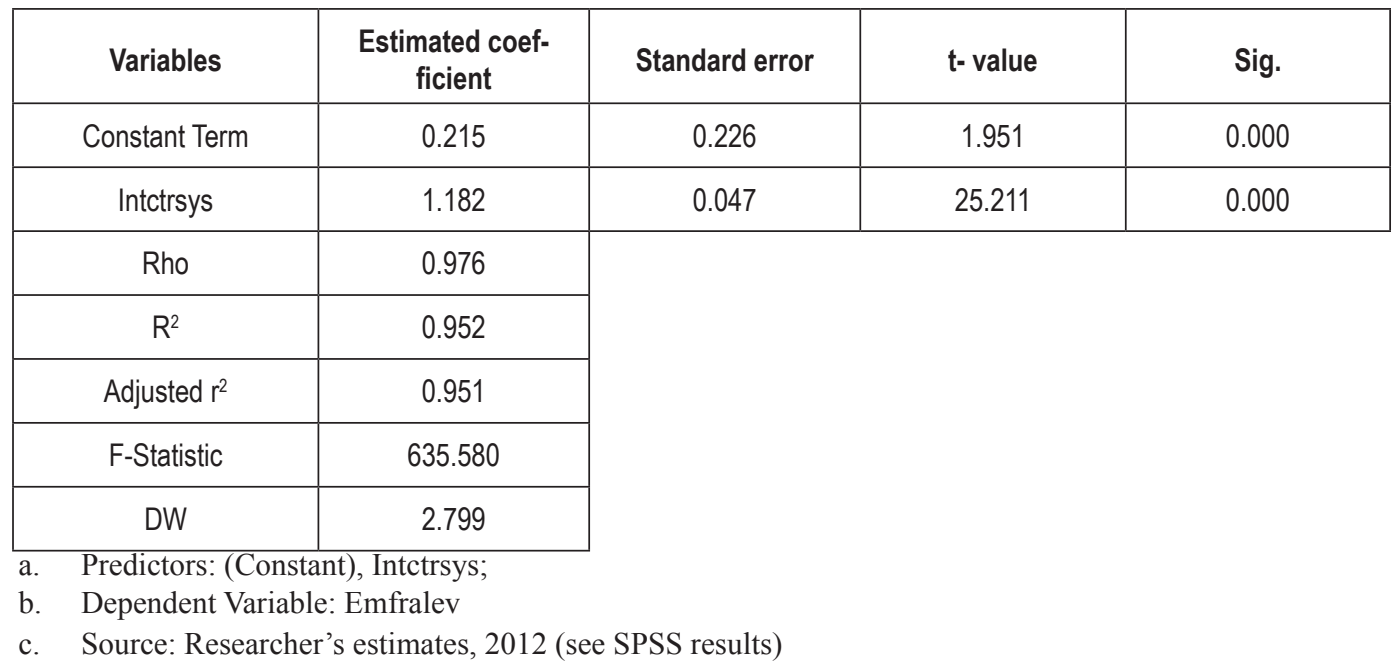

Table 2. Least square regression results for the effect of auditor's monitoring strength on the level of risk of employee fraud in the Nigerian public service.

\begin{tabular}{|c|c|c|c|c|}
\hline Variables & Estimated coefficient & Standard error & t- value & Sig. \\
\hline Constant Term & 1.622 & 0.271 & 5.992 & 0.000 \\
\hline Audmost & 1.131 & 0.071 & 15.925 & 0.000 \\
\hline Rho & 0.942 & & \\
\hline $\mathrm{R}^{2}$ & 0.888 & & \\
\hline Adjusted r & 884 & & \\
\hline F-Statistic & 253.99 &
\end{tabular}

a. Predictors: (Constant), Audmost

b. Dependent Variable: Emfralev

c. Source: Researcher's estimates, 2012 (see SPSS results) 
Joe DUKE II, Kechi A. KANKPANG. Effect of Fraud Risk Reduction Strategy on the Level of Employee Fraud in Nigerian Public Service Organizations

Table 3. Least square regression results for the effect of reward and compensation on the level of risk of employee fraud in the Nigerian public service.

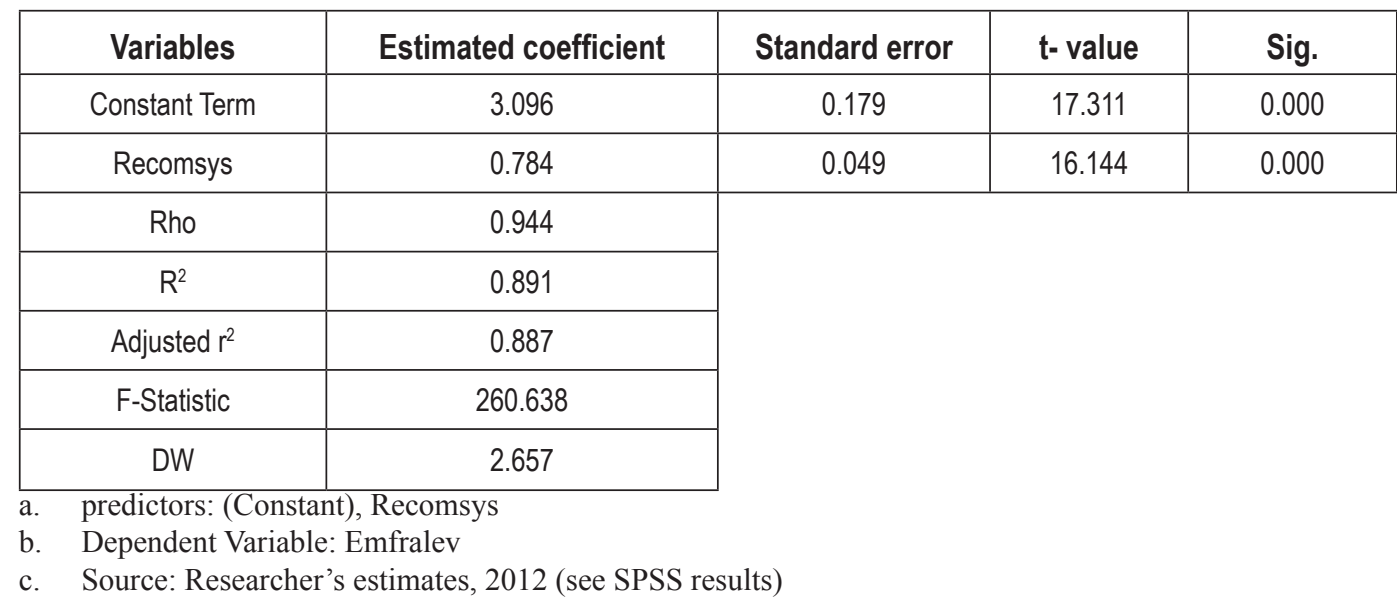

Table 4. Least square regression results for the effect of reduction in the level of risk of employee fraud on employee productivity in the Nigerian public service.

\begin{tabular}{|c|c|c|c|c|}
\hline Variables & Estimated coefficient & Standard error & t- value & Sig. \\
\hline Constant Term & 2.198 & 0.026 & 84.296 & 0.000 \\
\hline Rdfralev & 0.139 & 0.005 & 25.764 & 0.000 \\
\hline Rho & 0.977 & & \\
\hline$R^{2}$ & 0.954 & & \\
\cline { 1 - 2 } Adjusted r & 0.953 & & \\
\cline { 1 - 2 } F-Statistic & 663.800 & &
\end{tabular}

a. Predictors: (Constant), Rdfralev

b. Dependent Variable: Emprod

c. Source: Researcher's estimates, 2012 (see SPSS results) 
PROBLEMS OF MANAGEMENT IN THE $21^{\text {st }}$ CENTURY Volume 4, 2012

Table 5. Least square regression results for the effect of internal controls system, auditors' monitoring strength, and reward and compensation system on the level of risk of employee fraud in the Nigerian public service.

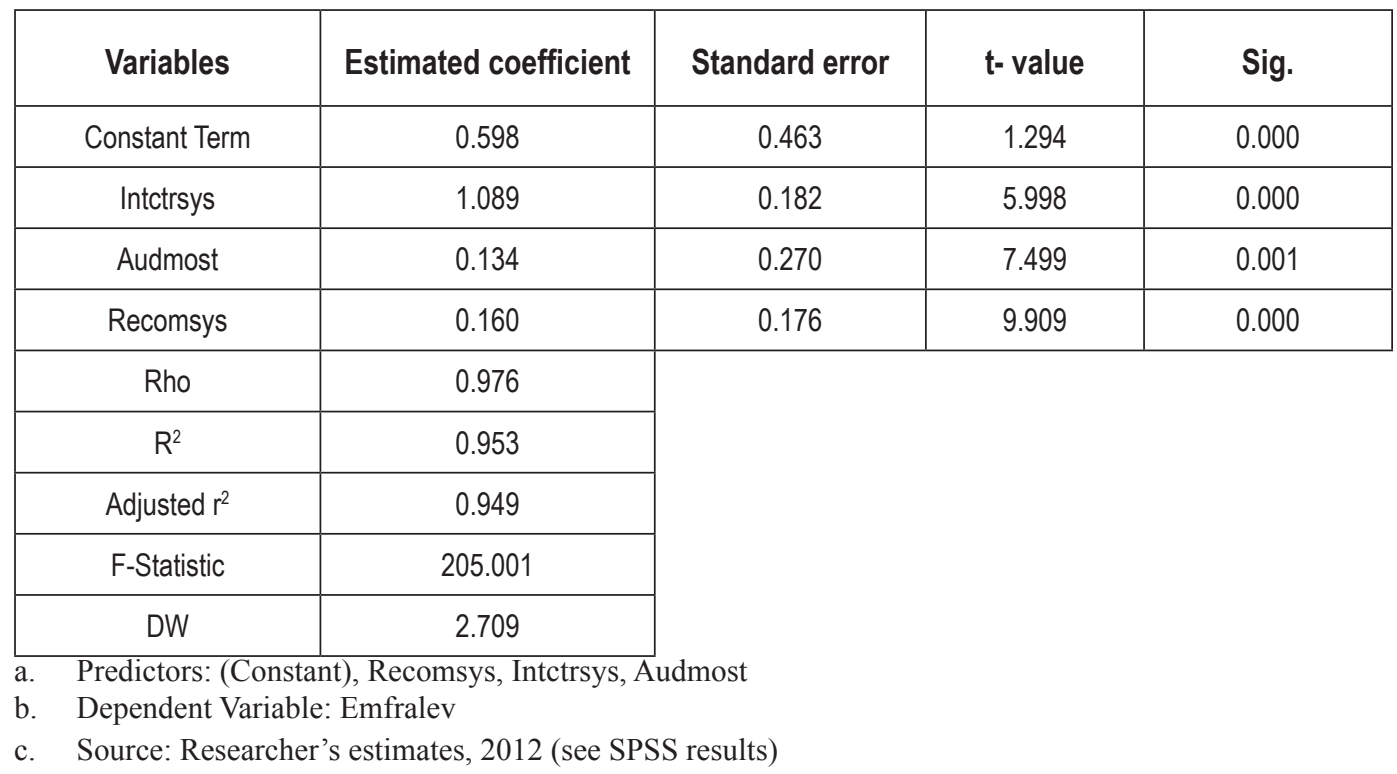

Table 6. Benchmark (Tabulated Values) using two tailed test.

\begin{tabular}{|c|c|}
\hline Table $F$ - Statistic $\mathrm{F}_{0.05}(1,262)$ & 3.84 \\
\hline Table F- Statistic $\mathrm{F}_{0.01}(1,262)$ & 6.63 \\
\hline Table Value $\mathrm{t}$-value $\mathrm{t}_{0.05}(\mathrm{~N}-\mathrm{k}=262)$ & 2.042 \\
\hline Table Value - - -value $\mathrm{t}_{0.10}(\mathrm{~N}-\mathrm{K}=262)$ & 1.697 \\
\hline
\end{tabular}

Source: Gujarati (2005)

Table 1 shows the effect of internal controls system on the level of risk of employee fraud in Nigerian public service organizations. It indicates that the model fits the data well, as measured by the adjusted coefficient of determination (Adjusted $\mathrm{R}^{2}$ ). The adjusted $\mathrm{R}^{2}$ value of 0.951 indicates that about $95.1 \%$ of the observed changes in the dependent variable, that is, reduction in the level of risk of employee fraud was explained by the independent variable: internal controls system. It follows that the remaining $4.9 \%$ was not accounted for by the model and was therefore represented in the usual stochastic error term. The high value of the adjusted R-squared did not occur by chance, since its overall statistical significance as measured by the F-statistic showed a high level [F-statistic $(1,261)=635.580$ compared to F0.05 $(1,261)=$ 3.84]. This confirms that the model had a high predictive power.

To examine the statistical significance of the individual variables in the model, the tstatistic value was used. First, the expected a priori sign confirmed the theoretical proposition that internal controls system is positively related to the level of risk of employee fraud. Specifically, the independent variable was found to be statistically significant at better than $1 \%$ level $[$ tcal $=25.211>$ t0.01 $=1.697]$. This was read from a two-tailed test table. Testing for the existence or otherwise of serial correlation in the residuals of the model, the Durbin Watson 
(DW) statistic was used. By rule of thumb, since the calculated DW value is 2.799 , which is

PROBLEMS

OF MANAGEMENT

IN THE $21^{\text {st }}$ CENTURY

Volume 4, 2012

between the expected values of the upper value $(\mathrm{Du})$ of the DW table and the 4 -DW value at $5 \%$ level, it is concluded that the model is free from auto-correlation. The estimates are therefore considered reliable.

Table 2 indicates the results of the test of a relationship between auditors' monitoring strength and reduction in the level of risk of employee fraud. Again, the model shows a high predictive power of the independent variable on the dependent variable. The adjusted R-squared value of 0.884 indicates that $88.4 \%$ of the observed changes in the dependent variable, reduction in the risk and level of employee fraud were explained by changes in the independent variable - auditors' monitoring strength. The remaining $11.6 \%$ was captured by the stochastic error term with its usual normality assumptions. The high F-statistic also confirmed that the high explanatory power of the independent variable is better, it could not have occurred by chance. A look at the statistical significance and the a priori sign of the variable in the model indicates that the independent variable was statistically significant at the conventional levels. Specifically, the independent variable was observed to be statistically significant at better than $1 \%$ level [tcal $=$ $15.925>$ t $0.01=1.697]$. The model was observed to be free from auto-correlation since the calculated value of the Durbin -Watson statistic is again at the "no correlation" region. This confirms the statistical reliability of the model.

Table 3 shows the effects of organizational reward and compensation system on the level of risk of employee fraud in Nigerian public service organizations. An adjusted R-squared value of 0.887 indicates that the model has a high predictive power at $88.7 \%$ and fits the data well. The high and statistically significant value of the F-statistic [F-stat. $(1,261)=260.638>$ F0.05 $(1,261)=3.84]$ also confirms the overall significance of the model and the predictive power of the independent variable. An examination of the statistical significance of the variables in this model indicates that the independent variable was statistically significant at better than $1 \%$ level $[\mathrm{tcal}=16.144>\mathrm{t} 0.01=1.697$ ] and carried the right a priori positive sign. Again, the DW statistic value 2.657 is within the region of "no-auto-correlation". This confirms the statistical significance of the model.

Table 4 shows the effect of reduction in the level of risk of employee fraud on the productivity of employees in the public service. It indicates that the model fits the data well as measured by the adjusted coefficient of determination (Adjusted $\mathrm{R}^{2}$ ). The adjusted $\mathrm{R}^{2}$ value of 0.955 indicates that $95.5 \%$ of the observed changes in the dependent variable, which is, productivity of employees, were explained by the independent variable - the level of risk of employee fraud. It follows therefore that the remaining $4.5 \%$ was not accounted for by the model and was therefore represented in the usual stochastic error term. This high value of the adjusted R-squared did not occur by chance, since its overall statistical significance as measured by the F-statistic showed high level [F-statistic $(1,261)=663.800$ compared to F0.05 $(1,261)=3.84]$. This confirms that the model had a high predictive power.

To examine the statistical significance of the model, the t-statistic value was used. First, the expected a priori sign confirmed the theoretical expectation that the level of risk of employee fraud is positively related to the productivity of employees in the public service. The result shows that the independent variable is statistically significant at better than $1 \%$ level $[\mathrm{tcal}=25.764>\mathrm{t} 0.01=1.697]$. The Durbin-Watson $(\mathrm{DW})$ statistic test was used to establish the existence or otherwise of serial correlation in the residuals of the model. By rule thumb, it is concluded that the model is free from auto-correlation and the estimates considered reliable, since the calculated DW value, 2.918 , is between the expected values at the upper value (Du) of the DW table and the 4-Du value at 5\% level.

Table 5 shows the combined effect of internal controls system, auditor's monitoring strength, and organizational reward and compensation on the level of risk of employee fraud in the public service. With an adjusted R-squared value of 0.949 or $94.9 \%$, it is confirmed that the 
PROBLEMS

OF MANAGEMENT

IN THE $21^{\text {st }}$ CENTURY

Volume 4, 2012

40

model has a high prediction power and fits the data well. The high and statistically significant value of the F-statistic [F-stat. $(1,261)=205.001>$ F0.05 $(1,261)=3.84$ ] confirms the overall significance of the model and the predictive power of the independent variable.

An examination of the model shows that the independent variables were statistically significant at a better than $1 \%$ level for each of the variables [tcal $=5.998 ; 7.499 ; 9.909>\mathrm{t} 0.01=$ 1.697] and carried the right a priori positive sign. Again, the DW statistic value, 2.709, is within the region of "no-auto-correlation". This confirms the statistical significance of the model.

\section{Test of Hypotheses}

H1: Internal controls system significantly reduces the level of risk of employee fraud in Nigerian public service organizations.

The aim of this hypothesis was to establish whether or not there is a significant relationship between internal controls system used and a reduction in the level of risk of employee fraud in Nigerian public service organizations. The results show a positive coefficient of determination of 0.954 . This indicates that there is a positive significant relationship between internal systems and the reduction of the level of risk of employee fraud in Nigerian public service organizations.

$\mathrm{H} 2$ : Auditors' monitoring strength significantly reduces the level of risk of employee fraud in Nigerian public service organizations.

This hypothesis sought to test whether a statistically significant relationship exists between auditors' monitoring strength and a reduction in the level of risk of employee fraud in Nigerian public service organizations. The results show a positive coefficient of determination of 0.888 between auditors' monitoring strength and the reduction in the level of risk of employee fraud in Nigerian public service organizations. This implies that stronger auditors' monitoring strength leads to a reduction in the level of risk of employee fraud in Nigerian public service organizations.

H3: The reward and compensation system significantly reduces the level of risk of employee fraud in Nigerian public service organizations.

This hypothesis sought to determine if a statistically significant relationship exists between reward and compensation system and the level of risk of employee fraud in Nigerian public service organizations. The estimated coefficient of determination was 0.891 , which indicates a significant relationship between reward and compensation system and the level of risk of employee fraud in public service organizations.

H4: Reduction in the level of fraud has a significant effect on the productivity of employees in Nigerian public service organizations.

The hypothesis sought to establish whether a reduction in the level of risk of fraud will lead to an increase in the productivity level of employees in public service organizations. The results show a positive relationship of 0.954 between reduction in the level of fraud risk and employee productivity. This therefore indicates that the level of risk of employee fraud has a significant effect on the productivity level of employees in Nigerian public service organizations.

\section{Discussion}

Analysis of the results of the study shows that internal controls system used significantly affects the level of risk of employee fraud. This finding corroborates the position of Wells (1997) that fraud risk reduction is a function of the effectiveness of fraud management (including internal controls) strategy used by an organization. It also tantamount to the empirical results of KPMG Forensic (2004) and Garner (2004) which were unanimous in concluding that the more effective the fraud risk reduction strategy used, the lower the occurrence of fraud in the organization. 
In this present study, auditors' monitoring strength was found to be associated with the level of risk of employee fraud. This finding confirms the propositions of DeAngelo (1981) and Watt and Zimmerman $(1981,1986)$ that audit quality is largely a function of the auditor's ability to discover and report breaches. The probability of discovering and reporting on infractions will depend to a considerable extent on the auditor's independence and monitoring strength. The higher the auditor's monitoring strength, the lower the incidence of client firm's use of aggressive and questionable accounting practices, fraud risk, and earnings mismanagement (Magee \& Tseng, 1990).

The study found that the nature and content of the reward and compensation system influences the occurrence of fraud. This result finds resonance with Olufidipe's (1994) argument that when an organization's personnel are adequately remunerated, employee fraud incidence tends to reduce. More instructively, the result confirms the earlier empirical findings of Agbase (2000), Nwankwo (1991) and Uzoka (1995), all of which identified poor staff remuneration as a key incentive for employee fraud in organizations. The finding of this study further reinforces the Employees Theft theory that holds that employees steal primarily as a result of workplace conditions.

Lastly, reduction in the level of fraud was found to have a significant effect on the contribution of employees to the attainment of the overall goals of the organization. This result synchronizes with the finding of Ernest and Young (2002) that unethical behaviour worsens productivity. It similarly agrees with the conclusions of the Giffin (1999) and Webley and Moore (2003) studies on the subject.

\section{Conclusions and Implications}

A key implication of the findings of this study is that the current internal control system used in Nigerian public service organizations is weak and largely ineffective, given the growing scale of reported employee fraud especially in the last 10 years. To stem the trend, it is necessary to provide a mechanism that is focused on early warning and prevention, rather than periodic audit and discovery as is the case now. This will best be approached by instituting a blend of physical, accounting, process and procurement procedures that are aimed at strengthening the control system.

Auditor's monitoring strength is a key deterrent of employee fraud. Again, given the recent scale and frequency of reported employee fraud, it is clear that auditors' monitoring strength in Nigerian public service organizations is currently low. To improve auditor's monitoring strength, a higher level of independence is imperative. Auditors therefore need to be unshackled from routine reporting and accountability tọ functional managers within the organization. This calls for a review and restructuring of the organizational architecture from what presently obtains in public service establishments in order to facilitate this independence.

The compensation and reward system used in Nigerian public service organizations is uncompetitive, and compares very unfavourably with other industrial sectors such as banking, oil and gas and telecommunications. The finding of this study implies that employee fraud has, in part, been facilitated by the relatively poor compensation level in the Nigerian public service. This situation may be responsible for the observably low productivity level in the public sector. Synchronizing public sector wage levels with those of the private sector industries may help resolve the fraud incidence, especially as it has been observed that the scale and frequency of reported cases of employee fraud is significantly lower in private firms. However, this finding requires further investigation in order to establish the extent and dimension of the problem.

There is a symbiotic relationship between the level of fraud and the productivity of employees. The relationship suggests that unethical behaviour fuels fraud, which in turn feeds low productivity. Instructively, an earlier finding by the Association of fraud Examiners (2006)

PROBLEMS

OF MANAGEMENT

IN THE $21^{\text {st }}$ CENTURY

Volume 4, 2012

41 
PROBLEMS

OF MANAGEMENT

IN THE $21^{\text {st }}$ CENTURY

Volume 4, 2012

shows that while fraud itself is often hard to spot, unethical behaviour, which underlines low productivity is manifest. Proper monitoring of work behaviour therefore can help in detecting fraud. Accordingly, as productivity of a staff drops, it is important to trace its causes and drivers. Typical causes include lack of espoused code of ethics, low level of trust between staffs, unfavourable work conditions and low morale. The effect is invariably deviant behaviour, misconduct and fraud.

While the prevalence of fraud in public service organizations appears to generally correlate with the deterioration of other societal infrastructures in the Nigerian system, there is however an indication that a number of organization-specific conditions are more responsible for the development. These conditions include lack of tenure (at executive levels), quality of staff, and a severe erosion of the true worth of salaried income. The end result of these is a weakening of the value-system and a generally poor organizational climate. Remedies for these are the establishment of clear job tenure, a more rigorous recruitment standard, and streamlining of pay with prevailing economic exigencies. Additionally, value orientation is critical in re-directing the accepted standards of behaviour of staffs. This can be achieved through continuous training, enlightenment and inculcation of acceptable ethical standards that could support the development and maintenance of a more appropriate organizational culture in the public service.

\section{References}

American Institute of Certified Public Accountants (AICPA) (1992). Exposures draft: Proposed statement on auditing standards consideration of fraud in a financial statement audit. New York: AICPA.

Ajibade, \& Co. (2011). Executive Summary of Anti-Corruption Legislations with a view to Advising Foreign Investors in Nigeria on Anti-corruption Programmes. Retrieved from http://spaajibade. com/resources/newarticles/Executive $\% 20$ Summary $\% 20$ of $\% 20$ the $\% 20$ ICPC $\% 20$ Act $1 \% 20$ jco. pdf

Ansari, S. (2004). Systems theory and management control (Teaching note). Retrieved from http:// freedownload.is/pdf/teaching-note-systems-theory-and-management-control1-2443009.html

Asomugha, E. M. (1997). Financial malpractices in banks. Journal of Professional Administration, 1, 24-30.

Awolabi, E. A. (2007). Corruption and financial crimes in Nigeria: Genesis, trend and consequences. Retrieved from http://www.cenbank.org/OUT/PUBLICATIONS/TRANSPARENCY/2007/ TRANSPARENCY2007.PDF

Comer, M. J. (1995). Investigating corporate fraud. Aldershot: Gower Publishers.

Cressey, D. R. (1993). Other people money. New York: Montchan Patterson Smith Publishers.

DeAngelo, L. (1981a). Auditor independence, 'Low balling', and disclosure regulation. Journal of Accounting and Economics, 12 (3), 113-127.

DeAngelo, L. (1981b). Auditor size and auditor quality. Journal of Accounting and Economics, 8 (5), 183-199.

Dopuch, N., King, P., \& Schwarte, D. (2001). Competition in auditing: An assessment of fourth symposium on auditing research. Chicago: University of Illinois Press.

Duke II, J., Kankpang, K. A., \& Okonkwo, G. (2012). Corporate governance as a driver of organizational efficiency in courier service firms: Empirical findings from Nigeria. Interdisciplinary Journal of Research in Business, 1 (11), 26-38.

Ethics Resource Center (2003). The 2003 National business ethics survey. Retrieved from http://www. ethics.org/resource/2003-national-business-ethics-survey-nbes

Gietzmen, R., \& Sen, B. (2002). Auditing the accounting firms. Financial World, 163 (20), 30 -31.

Hollinger, R. C., \& Clark, J. P. (1983). Theft by employees. Lexington: Lexington Books. 
Joe DUKE II, Kechi A. KANKPANG. Effect of Fraud Risk Reduction Strategy on the Level of Employee Fraud in Nigerian Public Service Organizations

Josephson Institute (2004). The hidden costs of unethical behavior. Retrieved from http://josephsoninstitute. org/pdf/workplace-flier_0604.pdf

Kidder, D. (2005). It is 'who I am', what I can get away with or what you've done to me? A multi - theory examination of employees misconduct. Journal of Business Ethics, 57 (4), 389-398.

McLean Park, J., Kidder, D., \& Gallagher, H. (1998). The contract of individual organizations. Research in Organizational Behaviour, 4 (2), 1-14.

McLean Park, J., \& Kidder, D. (1994). Till death do us part: Changing relationships in the 1990s. Trends in Organizational Behaviour, 1, 111-116.

Magee, R. P., \& Tseng M. (1990). Auditing pricing and independence. The Accounting Review, 65 (2), 315-321.

Mintz, S. M. (2004). Improving corporate governance systems: A stakeholder theory approach. Retrieved from http://aaahq.org/AM2004/cpe/Ethics/Forum_08.pdf

Morrison, W., \& Robbinson, S. (1997). When employees feel betrayed: A model of how psychological contract violation develops. Academy of Management Review, 22 (11), 226-236.

NAIJAFEED (2012). Nigeria fuel subsidy report shows $\$ 6.8$ billion lost due to fraud. Retrieved from file://C:/Users/JoeDukeII/Desktop/new\%20fraud\%20matters/nigeria-fuel-subsidy-reportshows-68bn-lost-due-to-fraud.html

NairaLand (2012, May, 13). Subsidy Fraud: Ifeanyi Uba (Capital Oil) Must Repay $\$ 5$ Billion Within 60 Days. Retrieved from file://C:/Users/JoeDukeII/Desktop/new\%20fraud\%20matters/subsidyfraud-ifeanyi-uba-capital.htm

Nwankwo, G. O. (1991). Bank management. Lagos: Landmark Publishers.

Nystrom, V. G. (1997). An analysis of auditor liability rules. Journal of Accounting Research, 32, 39-43.

Olufidipe, E. O. (1994). Fraud in the Nigerian economic development. The Nigerian Banker, 5, 126134.

Osae-Brown, A., \& Uzor, B. (2011). Bank fraud up 55\% as lenders lose N13 billion. Retrieved from http://www.businessdayonline.com/NG/index.php/news/76-hot-topic/26188-bank-fraud-up55-as-lenders-lose-n13-billion

Padilla, A. (2002). Can Agency Theory Justify The Regulation Of Insider Trading. The Quarterly Journal of Austrian Economics, 5 (1), 3-38

Raghunandan, K., Lewis, P., \& Evan, D. R. (1994). Auditor resignations and the market for audit services. Journal of Practice \& Theory, 18 (1), 124-129.

SecurLinx.com (2011). Biometrics reveal a staggering level of fraud in Nigeria. Retrieved from http:// securlinx.blogspot.com/2011/07/biometrics-reveal-staggering-level-of.html

Shongotola, I. O. (1994). Fraud detection and control: Role of branch management. The Nigerian Banker, 3, 56-61.

Soniyi, T. (2012, March 30). $\$ 32.8$ bn Pension Fraud: Perm Sec, 5 Others Remanded in Prison. This Day. Retrieved from file://C:/Users/JoeDukeII/Desktop/new\%20fraud\%20matters/N32.8bn\%20Pe nsion $\% 20$ Fraud $\% 20 \% 20$ Perm $\% 20$ Sec, $\% 205 \% 20$ Others\%20Remanded $\% 20$ in $\% 20$ Prison, $\% 20$ Articles\%20_\%20THISDAY\%20LIVE.htm

Thornhill, W. T. (1995). Forensic accounting: How to investigate financial fraud. New York: Irwin.

Transparency International (2011). Corruption perceptions index 2011. Retrieved from http://cpi. transparency.org/cpi2011/results/

Uche, C. U. (2001). Nigeria: Bank Fraud. Journal of Financial Crime, 8 (3), 265-275.

Watts, R. L., \& Zimmerman, J. L. (1981). Agency problems, auditing and the theory of the firm: Some empirical evidence. Journal of Law and Economics, 2, 613-618.

Watts, R. L., \& Zimmerman, J. L. (1986). Positive accounting theory. New Jersey: Prentice - Hall.

Webley, S., \& More, E. (2003). Does Business Ethics Pay? London: Institute of Business Ethics.

Wells, J. T. (1997). New approaches to fraud deterrence. The Chartered Accountant, 5, 53-55. 
OF MANAGEMENT

IN THE $21^{\text {st }}$ CENTURY

Volume 4, 2012

Advised by Constantin Bratianu, Academy of Economic Studies, Bucharest, Romania

Received: May 04, 2012

Accepted: June 21, 2012

Joe Duke II

PhD, Senior Lecturer, University of Calabar, No. 32a, Nelson Mandela Road, G. P. O. Box 1001, Calabar, Cross River State, 540001, Nigeria.

E-mail: joedukell@yahoo.com

Kechi A. Kankpang University of Calabar, No. 32a, Nelson Mandela Road, G. P. O. Box 1001, Calabar, Cross River State, 540001, Nigeria.

E-mail: kankpang_2000@yahoo.com 